\title{
Study on Relationship between Seasonal Temperatures and Municipal Wastewater Pollutant Concentration and Removal Rate
}

\author{
Shaoxiong Yuan ${ }^{1,2}$, Guangqing Huang ${ }^{1,2}$, Wenyin Chen, Zhanghe Chen ${ }^{3}$ and Xiaoling Yin ${ }^{2}$ \\ ${ }^{1}$ Guangzhou Institute of Geochemistry, Graduate School of the Chinese Academy of Sciences, 510640 Wushan, Guangzhou, Guangdong, \\ China \\ ${ }^{2}$ Guangdong Open Laboratory of Geospatial Information Technology and Application, Guangzhou Institute of Geography, 100 Xianlie Middle \\ Rd, 510070 Yuexiu, Guangzhou, Guangdong, China \\ ${ }^{3}$ College of Life Science, South China Normal University, 510631 Tianhe, Guangzhou, Guangdong, China
}

\begin{abstract}
In this study, the temperatures, pollutant concentrations and other indicators of municipal wastewater influent and effluent were tested for 7 months in 6 constructed wetland microcosms; the hydraulic retention time is 2 days. The results indicated that for both influent and effluent, there was a highly significant negative correlation $(\mathrm{P}<0.01)$ between the temperature and the pollutant concentrations, there was a significant difference $(\mathrm{P}<0.05)$ between seasonal temperatures, and the pollutant concentrations in summer and autumn were significantly different from those in winter $(\mathrm{P}<0.05)$. Furthermore, a regression analysis of pollutant concentration $(\mathrm{y})$ based on changes in water temperature (x) in different seasons was performed. The analysis revealed that the relationship has the form $\mathrm{y}=$ $\mathrm{a}-\mathrm{bx}+\mathrm{cx}^{21}$, that under certain circumstances, pollutant concentrations can be calculated based on the temperature, and that the concentrations of $\mathrm{NH}_{4}-\mathrm{N}$, Total Phosphorus (TP) and Soluble Reactive Phosphorus (SRP) had a significantly negative correlation with their removal rate $(\mathrm{P}<0.01)$. However, seasonal temperature clearly did not have a direct impact on the pollutant concentration, and some studies have indicated that the different manners in which urban residents use water as the temperature changes may be the real reason that the pollutant concentrations of municipal wastewater vary with seasonal temperature. Furthermore, when designing and operating constructed wetlands, the impact of the changes in pollutant concentrations generated by seasonal temperature should be fully considered, dilution and other means should be taken to ensure purification.
\end{abstract}

\section{Introduction}

From 1991 until 2011, the dominant Constructed Wetland (CW) research topics included water, nutrients, plants, and flow [1]. In developing countries, most researchers focus on the applications of CWs for removal of various contaminants from wastewater [2]. In most of the research regarding $\mathrm{CW}$ treatment of municipal wastewater, the purification effect is the main topic [3][7]. Many CW scholars have recognized the influence of temperature on the treatment effect, water temperature affected denitrification rates [8], the percentage reduction in coliforms was lower during winter compared to all other seasons [9], the removal rate of soluble phosphorus is lower than $30 \%$ after November [10], the removal rates of DON, $\mathrm{NH}_{4}{ }^{+} \mathrm{N}$ and $\mathrm{TN}$ were significantly temperaturedependent [11], segmented regression analysis identified a breakpoint at $14.2^{\circ} \mathrm{C}$ for wastewater temperature that caused variations in $\mathrm{TN}$ and $\mathrm{NO}_{3}-\mathrm{N}$ concentration reduction performances [12]. Hydrilla verticillata grew slower in $15^{\circ} \mathrm{C}$ than in $25^{\circ} \mathrm{C}$ and $30^{\circ} \mathrm{C}$, and displayed lower TN and TP removal rates [13]. Because the treatment wetlands are solar powered ecosystems, Solar radiation will affect the temperature of the water and soils in the wetland, this cause changes in microbial activity and vegetation cycle, which in turn creates changes in water quality improvement [14]. Still not so many scholars have considered the seasonal relationships between temperature and pollutant concentrations, the relationships between pollutant concentrations and the removal of pollutants from municipal wastewater.

In this study, 6 constructed wetlands were constructed, and the temperature, pollutants, and pollutant removal rate were measured. We hoped to determine the relationships among those indexes and develop a more reasonable explanation for some of the problems of municipal wastewater purification due to seasonal changes.

\section{Materials and methods}

The constructed wetlands are located in Guangzhou City, Guangdong Province, China, South China Normal University Biological Park, within the latitude range of $23^{\circ} 8^{\prime} 29.89^{\prime \prime}-23^{\circ} 8^{\prime} 0.94^{\prime \prime} \mathrm{N}$ and longitude range of $113^{\circ} 21^{\prime}-$ $113^{\circ} 21^{\prime} 1.11^{\prime \prime} \mathrm{E}$ in a subtropical monsoon zone. Six adjacent pools, each 3.5 meters long, 3 meters wide and 0.5 meters deep, were constructed. As this study tried to 
explore the relationship between temperature and the pollutant concentration, only Eichhornia crassipes and Hydrilla verticillata were planted, the field studies did not involve any vertebrate, endangered or protected species.

Six constructed wetland, designated C1 through C6, were divided into 3 types of microcosms, each with 2 replicates. Eichhornia crassipes was planted in $\mathrm{C} 1$ and $\mathrm{C} 2$, Hydrilla verticillata was planted in $\mathrm{C} 4$ and $\mathrm{C} 5$, and $\mathrm{C} 3$ and $\mathrm{C} 6$ were used as control.

The wastewater used in the experiment was an equal mixture of municipal wastewater from the teacher village buildings and tap water. When the sewage and tap water were evenly mixed, 5 water samples were taken from each of the pools, near the 4 corners and the middle of the constructed wetland. The ammonia nitrogen $\left(\mathrm{NH}_{4}-\mathrm{N}\right)$, Total Phosphorus (TP), Soluble Phosphorus (SRP), Chemical Oxygen Demand (COD), and biochemical oxygen demand for five days $\left(\mathrm{BOD}_{5}\right)$ were measured immediately using standard methods [15]; the Air Temperature (AT) and Water Temperature (WT) were measured at the same time (the influent samples), and 2 days later, the temperatures and water pollutants were measured in the same manner (the effluent samples).

An analysis of variance was performed on all data. Duncan's new Multiple Range Test (DMRT) was performed to test for significant differences between seasons. The Pearson correlation coefficient was used to test for correlations among the seasonal temperatures, sewage pollutants, and percentage removal of pollutants. DMRT, the Pearson correlation analyses, and regressions were performed using IBM SPSS; Figures were made by IBM SPSS \& Origin 9

\section{Results}

\subsection{Relationships between influent temperature and pollutants}

The influent AT and WT exhibited a significantly negative correlation with the influent $\mathrm{NH}_{4}-\mathrm{N}$, TP, SRP, COD, and $\mathrm{BOD}_{5}$ (Table 1). From summer to winter, both the AT and WT declined, whereas most of the pollutant concentrations increased (Figure 1). There was a significant difference among seasonal temperatures $(\mathrm{P}<0.05)$. The average AT in the 3 seasons differed from each other by $6-7^{\circ} \mathrm{C}$, and the average WT differed by approximately $7^{\circ} \mathrm{C}$. The COD content in autumn was approximately $40 \%$ greater than that in summer, whereas the COD content in winter was approximately $100 \%$ greater than that in autumn. Other pollutants did not exhibit a significant difference between summer and autumn, but the concentrations of pollutants in summer and autumn were significantly different from that in winter $(\mathrm{P}<0.05)$. The concentrations of $\mathrm{NH}_{4}-\mathrm{N}, \mathrm{TP}, \mathrm{SRP}$ and $\mathrm{BOD}_{5}$ in winter were approximately $160 \%, 104 \%$, $103 \%$ and $76 \%$ greater, respectively, than the corresponding concentrations in summer and autumn.

The Concentration-Water Temperature Curve (C-WT) was drawn according to the change in concentration of pollutants at different WTs. A regression analysis was performed to obtain the equation and correlation (Figure 2 ). The general formula used was $y=a-b x+c x^{2}$, where $a>$ $0, b>0$, and $c>0$, ' $y$ ' is the concentration of some pollutant (mgL- $1 /$ molL-1), and ' $\mathrm{x}$ ' is WT $\left({ }^{\circ} \mathrm{C}\right)$. Table 2 showed the equations of the influent concentration of pollutants and water temperature curve. The results indicated that when the WT was less than $30^{\circ} \mathrm{C}$, the pollutant concentrations of the water decreased as the temperature increased; when WT was greater than $30^{\circ} \mathrm{C}$, the pollutant concentrations of the water increased as the temperature increased.

None of the indicators of water inflow in the three types of treatment exhibited any significant difference from each other.

Table 1. Correlations among Air Temperature (AT), water temperature (WT) and sewage pollutants of influent samples.

\begin{tabular}{ccccccc}
\hline & & \multicolumn{3}{c}{ Influent Pollutant Concentrations } \\
\cline { 2 - 7 } & $\mathbf{N H}_{4}-\mathbf{N}$ & $\mathbf{T P}$ & $\mathbf{S R P}$ & $\mathbf{C O D}$ & BOD $_{5}$ \\
\hline AT & $\begin{array}{c}\text { Pearson } \\
\text { Correlation } \\
\text { Sig. (2- } \\
\text { tailed) }\end{array}$ & $-.832^{* *}$ & $-.604^{* *}$ & $-.495^{* *}$ & $-.785^{* *}$ & $-.532^{* *}$ \\
WT & $\begin{array}{c}\text { Pearson } \\
\text { Correlation } \\
\text { Sig. (2- } \\
\text { tailed) }\end{array}$ & $-.838^{* *}$ & $-.627^{* *}$ & $-.514^{* *}$ & $-.794^{* *}$ & $-.519 * *$ \\
& .000 & .000 & .000 & .000 & .000 \\
\hline
\end{tabular}

AT: air temperature; WT: water temperature; **: Correlation is significant at the 0.01 level (2-tailed).

Table 2. Equation of the influent sample pollutant Concentrations and Water Temperature (C-WT) curve.

\begin{tabular}{lll}
\hline & Influent sample C-WT & $\mathrm{R}^{2}$ \\
\hline $\mathrm{C}_{\mathrm{NH} 4-\mathrm{N}}-\mathrm{WT}$ & $\mathrm{y}=74.368-4.631 \mathrm{x}+0.76 \mathrm{x}^{2}$ & $0.863^{* *}$ \\
$\mathrm{C}_{\mathrm{TP}}-\mathrm{WT}$ & $\mathrm{y}=6.624-0.389 \mathrm{x}+0.006 \mathrm{x}^{2}$ & $0.506^{* *}$ \\
$\mathrm{C}_{\mathrm{SRP}}-\mathrm{WT}$ & $\mathrm{y}=9.649-0.657 \mathrm{x}+0.012 \mathrm{x}^{2}$ & $0.595^{* *}$ \\
$\mathrm{C}_{\mathrm{COD}}-\mathrm{WT}$ & $\mathrm{y}=403.384-24.187 \mathrm{x}+0.396 \mathrm{x}^{2}$ & $0.767^{* *}$ \\
$\mathrm{C}_{\mathrm{BOD} 5}-\mathrm{WT}$ & $\mathrm{y}=98.187-5.417 \mathrm{x}+0.089 \mathrm{x}^{2}$ & 0.329 \\
**. Correlation & is significant at the 0.01 level. C-WT: \\
$\begin{array}{l}\text { concentration-water temperature curve; } \mathrm{R}^{2} \text { : coefficient of } \\
\text { determination. }\end{array}$
\end{tabular}

\subsection{Relationship between effluent temperature and pollutants}

The effluent AT and WT still exhibited a significantly negative correlation with the effluent $\mathrm{NH}_{4}-\mathrm{N}, \mathrm{TP}, \mathrm{SRP}$, COD, and $\mathrm{BOD}_{5}$ (Table 3). The effluent AT and WT and the concentration of pollutants changed in a manner similar to the water inflow, i.e., the concentration of pollutants generally increased as the temperature declined (Figure 3). The effluent AT, WT and $\mathrm{NH}_{4}-\mathrm{N}$ exhibited significant differences among seasons $(\mathrm{P}<0.05)$. The AT in summer was approximately $5^{\circ} \mathrm{C}$ greater than that in autumn, the AT in autumn was approximately $13^{\circ} \mathrm{C}$ greater than that in winter, and the WT values in the three seasons differed from each other by $8-9^{\circ} \mathrm{C}$. The $\mathrm{NH}_{4}-\mathrm{N}$ increased by approximately $160 \%$ on a seasonal basis from summer to winter. The concentrations of other effluent pollutants did not exhibit any significant difference between summer and autumn, but the 
concentrations of pollutants in summer and autumn were significantly different from those in winter $(\mathrm{P}<0.05)$. The concentrations of TP, SRP, COD and $\mathrm{BOD}_{5}$ in winter were approximately $190 \%, 250 \%, 120 \%$ and $160 \%$ greater, respectively, than the corresponding concentrations in summer and autumn.

Table 3. Correlations among AT, WT and pollutant concentrations of effluent samples.

\begin{tabular}{ccccccc}
\hline & \multicolumn{5}{c}{ Effluent Pollutant Concentrations } \\
\cline { 2 - 7 } & $\mathrm{NH}_{4}-\mathrm{N}$ & $\mathrm{TP}$ & $\mathrm{SRP}$ & $\mathrm{COD}$ & $\mathrm{BOD}_{5}$ \\
\hline $\mathrm{AT}$ & $\begin{array}{c}\text { Pearson } \\
\text { Correlation } \\
\text { Sig. (2- }\end{array}$ & $-.912^{* *}$ & $-.744^{* *}$ & $-.686^{* *}$ & $-.802^{* *}$ & $-.580^{* *}$ \\
& $\begin{array}{c}\text { tailed) } \\
\text { WT }\end{array} \begin{array}{c}\text { Pearson } \\
\text { Correlation } \\
\text { Sig. (2- } \\
\text { tailed) }\end{array}$ & $-.882^{* *}$ & $-.647^{* *}$ & $-.607^{* *}$ & $-.670^{* *}$ & $-.384^{*}$ \\
& .000 & .000 & .000 & .000 & .012 \\
\hline AT:
\end{tabular}

AT: air temperature; WT: water temperature; *: Correlation is significant at the 0.05 level (2-tailed); **:Correlation is significant at the 0.01 level (2-tailed).

The C-WT curve was drawn according to the change of concentration of pollutants at different effluent WTs.
A regression analysis was performed to obtain the equation and correlation (Figure 4). Table 4 showed the equations of the effluent concentration of pollutants and water temperature curve. The results are similar to the CWT curve of water inflow, and the trends in the concentrations of all pollutants reversed at approximately $30^{\circ} \mathrm{C}$.

Table 4. Equation of the effluent sample pollutant concentrations and water temperature (C-WT) curve.

\begin{tabular}{lll}
\hline & Effluent sample C-WT & $\mathrm{R}^{2}$ \\
\hline $\mathrm{C}_{\mathrm{NH} 4-\mathrm{N}}-\mathrm{WT}$ & $\mathrm{y}=43.277-2.444 \mathrm{x}+0.036 \mathrm{x}^{2}$ & $0.857^{* *}$ \\
$\mathrm{C}_{\mathrm{TP}}-\mathrm{WT}$ & $\mathrm{y}=4.618-0.274 \mathrm{x}+0.004 \mathrm{x}^{2}$ & $0.527^{* *}$ \\
$\mathrm{C}_{\mathrm{SRP}}-\mathrm{WT}$ & $\mathrm{y}=4.271-0.264 \mathrm{x}+0.004 \mathrm{x}^{2}$ & 0.477 \\
$\mathrm{C}_{\mathrm{COD}}-\mathrm{WT}$ & $\mathrm{y}=252.773-14.975 \mathrm{x}+0.246 \mathrm{x}^{2}$ & $0.627^{* *}$ \\
$\mathrm{C}_{\mathrm{BOD} 5}-\mathrm{WT}$ & $\mathrm{y}=69.907-4.659 \mathrm{x}+0.082 \mathrm{x}^{2}$ & 0.393 \\
\hline
\end{tabular}

C-WT: concentration-water temperature curve; $\mathrm{R}^{2}$ : coefficient of determination; **: Correlation is significant at the 0.01 level.

The effluent AT, WT and $\mathrm{NH}_{4}-\mathrm{N}$ did not exhibit any significant difference among the three types of treatment, but the concentrations of other pollutants exhibited a significant difference between Eichhornia crassipes microcosm and control microcosm $(\mathrm{P}<0.05)$.

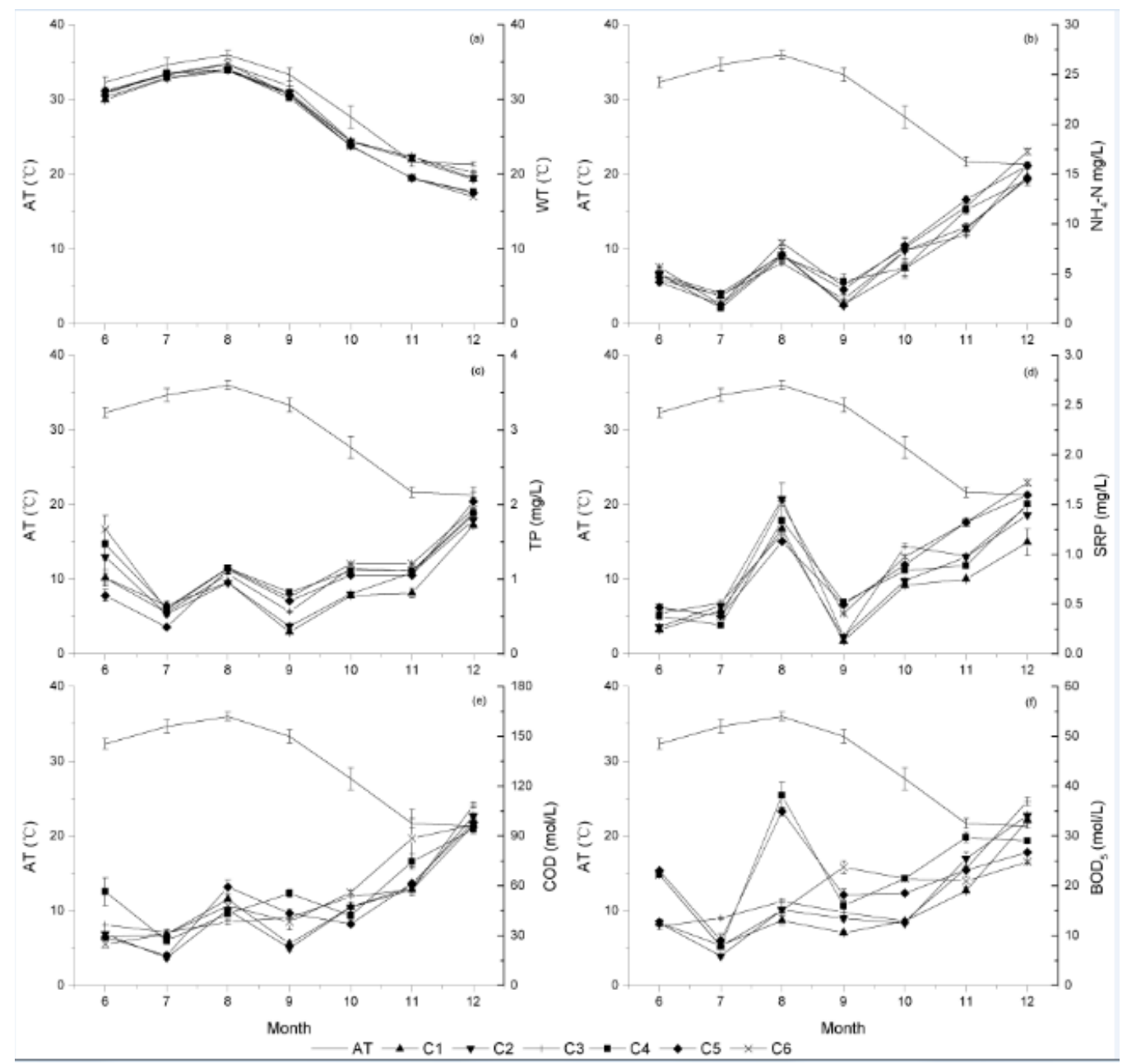

Figure 1. The temperature and pollutant concentrations of influent samples. AT: air temperature; WT: water temperature; C1-C6: Constructed wetland 1-6; (a) Relationship between air temperature and water temperature; (b) Relationship between air temperature and $\mathrm{NH}_{4}-\mathrm{N}$ concentrations; (c) Relationship between air temperature and TP concentrations; (d) Relationship between air temperature and SRP concentrations; (e) Relationship between air temperature and COD concentrations; (f) Relationship between air temperature and BOD5 concentrations. 

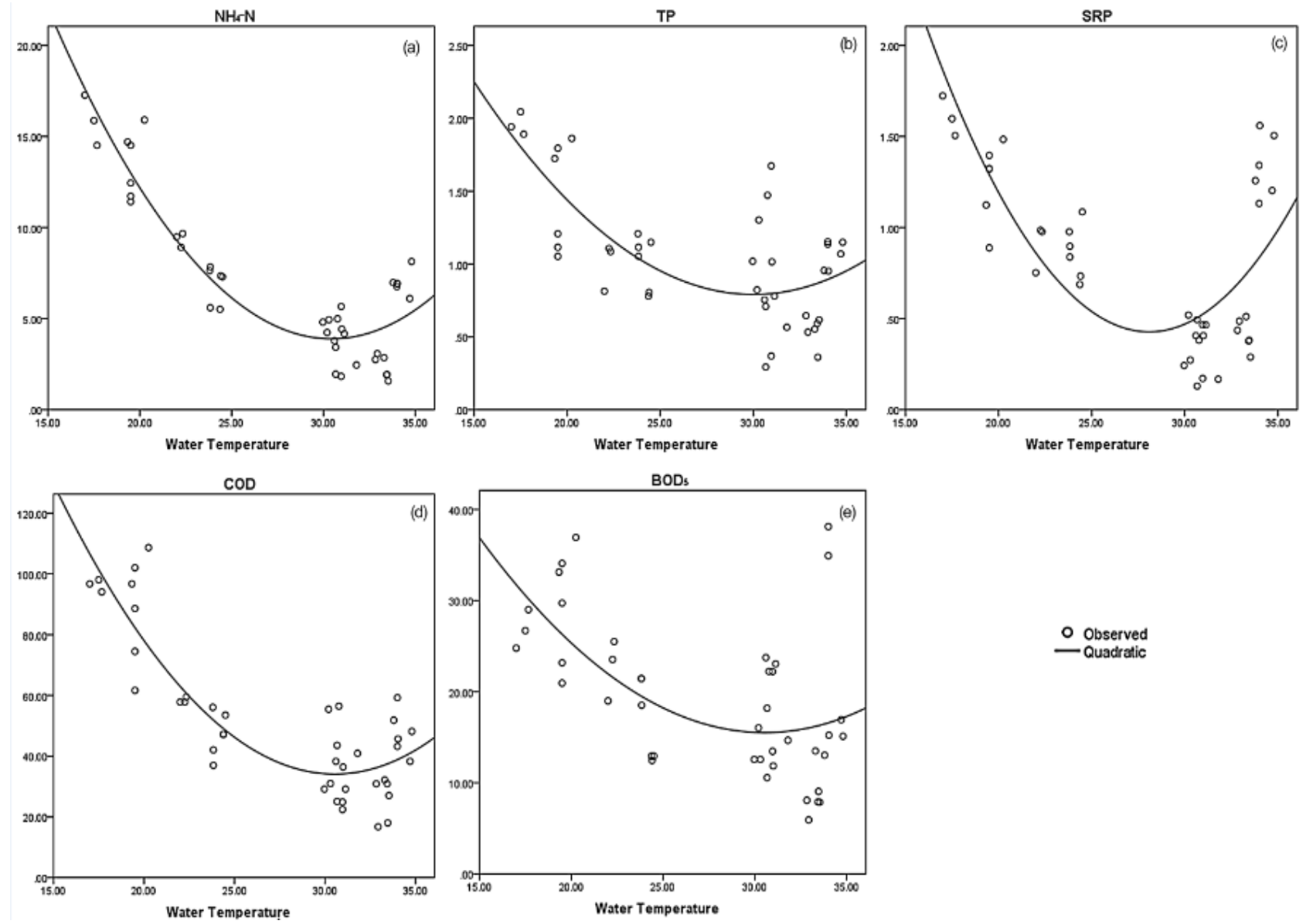

Figure 2. Quadratic Curve Estimation of influent sample pollutants concentration and water temperature. (a) $\mathrm{NH}_{4}-\mathrm{N}$ concentrationwater temperature curve; (b) TP concentration-water temperature curve; (c) SRP concentration-water temperature curve; (d) COD concentration-water temperature curve; $(\mathrm{e}) \mathrm{BOD}_{5}$ concentration-water temperature curve.

\subsection{Relations among average temperature, pollutants and its removal rate}

Similar to the findings of many scholars, the average temperature was correlated with the removal rate of some pollutants [11]-[13]. In this experiment, the hydraulic retention time of municipal wastewater is 2 days. The average AT and WT were significantly correlated with the removal rate of the $\mathrm{NH}_{4}-\mathrm{N}(\mathrm{P}<0.01)$, along with the removal rate of the TP and SRP $(\mathrm{P}<0.05)$, but were not correlated with the removal rates of $\mathrm{COD}$ and $\mathrm{BOD}_{5}$ (Table 5). The average temperatures in the three seasons differed by $7-8^{\circ} \mathrm{C}$ from each other, exhibiting a significant difference $(\mathrm{P}<0.05)$. The removal rates of the $\mathrm{COD}$ and $\mathrm{BOD}_{5}$ in the three seasons were not different from each other. The removal rates of $\mathrm{NH}_{4}-\mathrm{N}$ in autumn and winter were significantly less than that in summer $(\mathrm{P}$ $<0.05)$. The removal rate of the TP and SRP in winter was significantly less than that in summer $(\mathrm{P}<0.05)$, but there was no significant difference between neighbouring seasons.

$\mathrm{NH}_{4}-\mathrm{N}$, TP and SRP exhibited a significantly negative correlation with their removal rates $(\mathrm{P}<0.01)$; the concentrations of other pollutants were not significantly correlated with their removal rates.
The average temperatures in the three types of treatment were not significantly different, but Eichhornia crassipes microcosm exhibited significantly greater removal rates of $\mathrm{NH}_{4}-\mathrm{N}, \mathrm{COD}$ and $\mathrm{BOD}_{5}$ compared with Hydrilla verticillata microcosm and control microcosm, and it had significantly greater removal rates of TP and SRP compared with control microcosm. There was no significant linear relationship between the average temperature and removal rates of the pollutants.

Table 5. Correlations among the average AT, WT and removal rate of pollutants.

\begin{tabular}{ccccccc}
\hline & & \multicolumn{5}{c}{ Removal Rate } \\
\cline { 3 - 7 } & & $\mathrm{NH}_{4}-\mathrm{N}$ & $\mathrm{TP}$ & $\mathrm{SRP}$ & $\mathrm{COD}$ & $\mathrm{BOD}_{5}$ \\
\hline $\mathrm{AT}$ & $\begin{array}{c}\text { Pearson } \\
\text { Correlation } \\
\text { Sig. (2- } \\
\text { tailed) }\end{array}$ & $.670^{* *}$ & $.349^{*}$ & $.350^{*}$ & -.046 & -.062 \\
$\mathrm{WT}$ & $\begin{array}{c}\text { Pearson } \\
\text { Correlation } \\
\text { Sig. (2- } \\
\text { tailed) }\end{array}$ & $.695^{* *}$ & .024 & .023 & .773 & .696 \\
& .000 & .017 & .022 & .616 & .451 \\
\hline
\end{tabular}

AT: air temperature; WT: water temperature; *: Correlation is significant at the 0.05 level (2-tailed); **: Correlation is significant at the 0.01 level (2-tailed). 

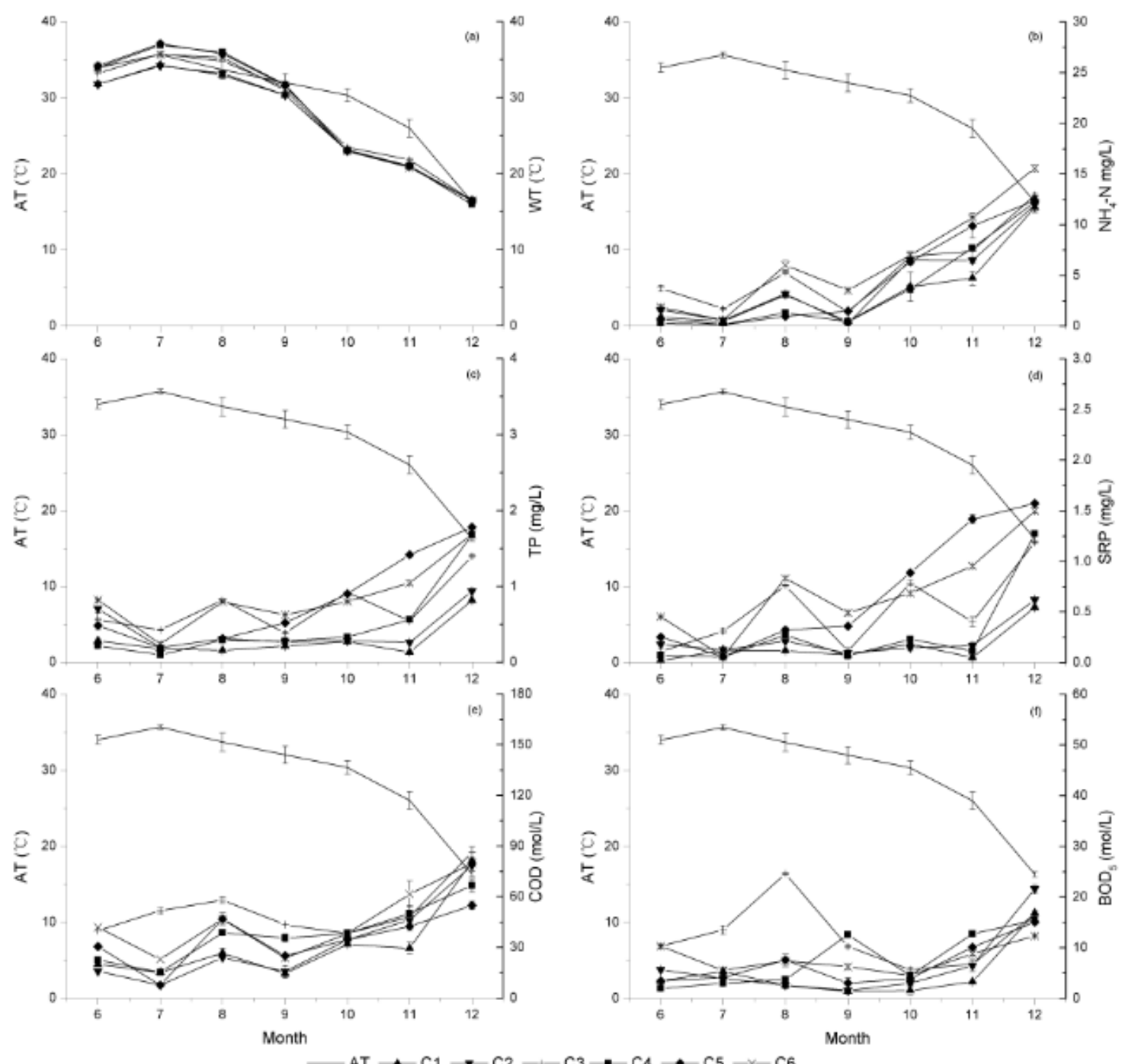

Figure 3. The temperature and pollutant concentrations of effluent samples. AT: air temperature; WT: water temperature; C1-C6: Constructed wetland 1-6. (a) Relationship between air temperature and water temperature. (b) Relationship between air temperature and $\mathrm{NH}_{4}-\mathrm{N}$ concentrations. (c) Relationship between air temperature and TP concentrations. (d) Relationship between air temperature and SRP concentrations. (e) Relationship between air temperature and COD concentrations. (f) Relationship between air temperature and $\mathrm{BOD}_{5}$ concentrations.

\section{Discussion}

Seasonal temperature influences the purifying effect of wetlands because of the effects of temperature on the growth of plants and microorganisms in wetlands [11], [16]-[18], but it does not have a direct impact on the concentrations of pollutants. Wei and Wan studied the characteristics of ammonia nitrogen pollution in an inner river branch and demonstrated that the concentration of pollutants in municipal wastewater is related to seasonal change [19]. They believed that the seasonal change in the concentration of ammonia nitrogen in the river branch was related mostly to the seasonal change in the quantity of water resources. In this study, municipal wastewater was extracted on days without rainfall to prevent the diluting effect of the rainwater. We observed that water consumption in the Guangzhou is greatly influenced by the season [20]. Along with the increase in seasonal temperature, the water consumption in July and August is relatively high. Compared with the months with low water consumption, high levels of water consumption in
July and August may dilute the pollutants. As a result, the experiment demonstrated that the concentration of pollutants decreased as the temperature increased. This is reflects the different manners in which urban residents use water as the temperature changes, which may be the real reason that the concentration of pollutants in municipal wastewater varies with seasonal temperature.

The experimental results indicated that some concentrations of pollutants might have a negative correlation with their removal rates when constructed wetlands are used to treat municipal wastewater. Therefore, in addition to the influence of seasonal temperature on the treatment efficiency, which can be related to the growth of plants in the wetland, we should also pay attention to the influence of seasonal changes in the concentration of sewage on the treatment efficiency.

In this paper, the average temperature was correlated with the removal rate of some pollutants, this's quite similar to the findings of many scholars. Mechanism of the changes in the removal rate of pollutants have been widely discussed, removal of pollutants in CWs mainly base on the plant absorption and microbial decomposition, 
the temperature will affect the growth of plants and microbial, as temperature varies with the seasons, removal rate of pollutants changes in different seasons [11]-[13], [16]-[18]. Seasonal changes have a greater effect on NH4-N removal rate, mainly due to the removal is based on the action of microorganisms, temperature decrease resulting the microbial growth rate and activity decrease, especially nitrifying bacteria [21]. Kuschk et al [22] showed that, nitrification is subject to temperature limitations in all seasons, denitrification significantly limited by seasonal temperature of less than $15^{\circ} \mathrm{C}$. Temperature also affected the transformations of glycogen and polyhydroxyalkanoates, and the activities of exopolyphosphatase and polyphosphate kinase activities, so the phosphorus removal rate will be affected by seasonal temperature [23].
In this study, tap water was used directly to dilute wastewater before the experiment for the purpose of preventing the treatment efficiency from being reduced when excessive concentrations of pollutants stop the growth of plants in the wetland. Therefore, several questions remain. For example, when we use large constructed wetlands to treat wastewater, in lowtemperature seasons, is it necessary to reduce the damage of high concentrations of pollutants to the plants in the wetlands and improve the treatment efficiency in wetland via dilution? If necessary, what type of water should be used for dilution? Is it feasible to dilute wastewater by adding natural water during operations? An in-depth investigation is needed to eliminate the influence of seasonal changes in the concentrations of pollutants on the efficiency of treating sewage using constructed wetlands.
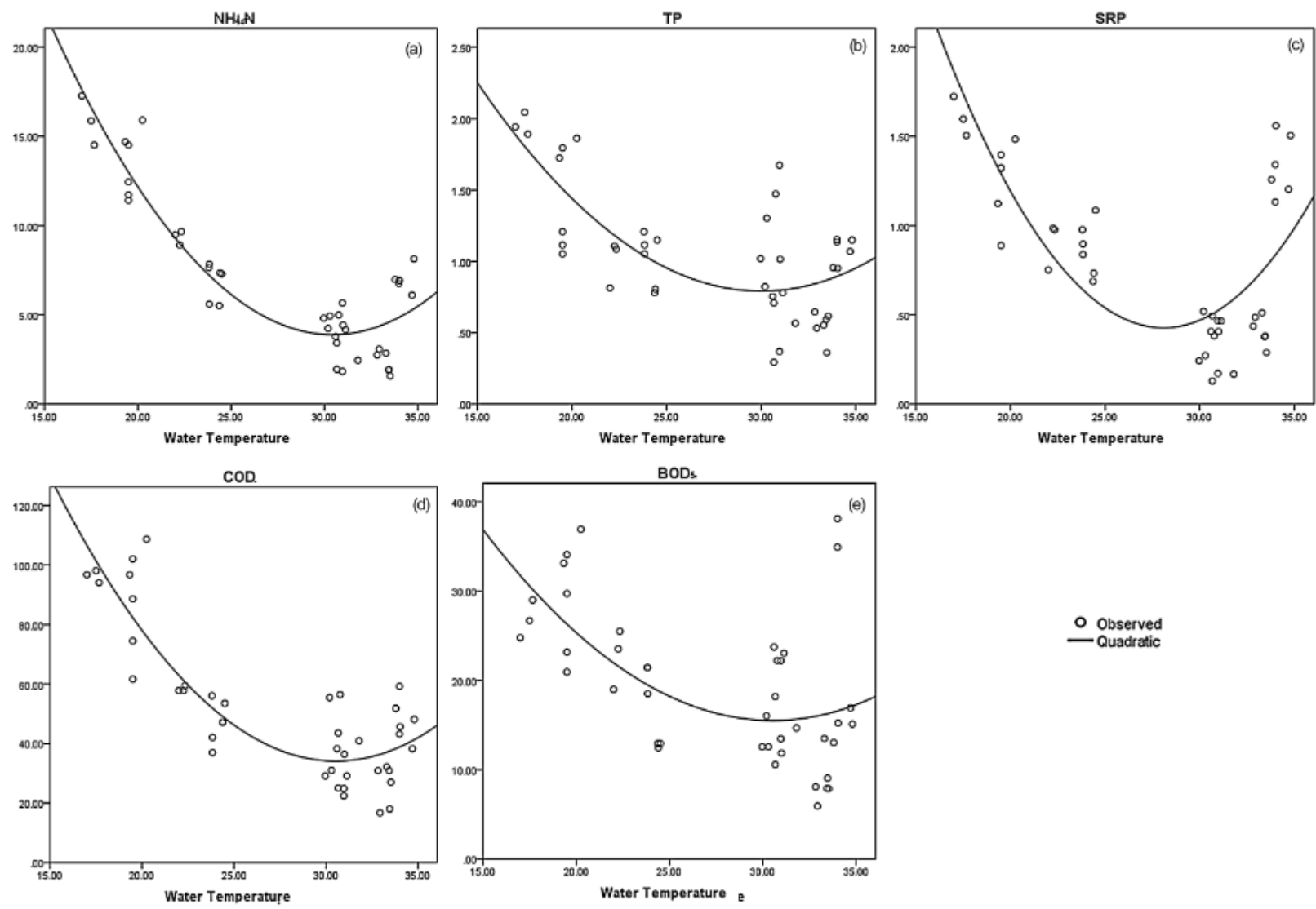

Figure 4. Quadratic Curve Estimation of effluent sample pollutants concentration and water temperature. (a) $\mathrm{NH}_{4}-\mathrm{N}_{\text {concentration- }}$ water temperature curve; (b) TP concentration-water temperature curve; (c) SRP concentration-water temperature curve; (d) COD concentration-water temperature curve; $(\mathrm{e}) \mathrm{BOD}_{5}$ concentration-water temperature curve.

\section{Conclusion}

In the experiment, seasonal temperature exhibited a significantly negative correlation with the concentration of pollutants in the water inflow of the municipal wastewater and the concentration of pollutants after the wastewater was treated for 2 days $(\mathrm{P}<0.01)$. The concentration of wastewater pollutants increased as the temperature declined from summer to winter. In contrast with the small difference in the concentration of pollutants between summer and autumn, the concentration of pollutants in summer and autumn was significantly different from that in winter $(\mathrm{P}<0.05)$. The average temperature was significantly correlated with the removal rates of TP, SRP and $\mathrm{NH}_{4}-\mathrm{N}$ but was not significantly correlated with the removal rates of COD and $\mathrm{BOD}_{5} . \mathrm{NH}_{4} \mathrm{~N}, \mathrm{TP}$ and $\mathrm{SRP}$ exhibited a significantly negative correlation with their removal rates $(\mathrm{P}<0.01)$, but other pollutants did not exhibit any significant correlations with their removal rates. Regression analysis of pollutant concentration (y) based on changes in water temperature $(\mathrm{x})$ in different seasons was performed, and found that they have the formula ' $y=a-b x+c x^{2}$, , under certain circumstances, pollutant concentrations can be calculated by temperature. 


\section{Acknowledgment}

This work was supported by the National Natural Science Foundation of China under grant numbers 30470346 and 41271029, the Major Science and Technology Production Planning Initiate Project of Guangdong Academy of Sciences, China, under grant number zdccyd201304, the Science and Technology Planning Project of Guangdong Province, China, under grant numbers 2013B060500067, 2013B060500068, 2013B060500072, and 2015B070701020.

\section{References}

1. W. Zhi, G. Ji, Constructed Wetlands, 1991-2011: A Review of Research Development, Current Trends, and Future Directions, Science of the Total Environment, 441(0):19-27, (2012)

2. D. Q. Zhang, K. Jinadasa, R. M. Gersberg, Y. Liu, W. J. Ng, S. K. Tan, Application of Constructed Wetlands for Wastewater Treatment in Developing Countries - A Review of Recent Developments (2000-2013), Journal of Environmental Management, 141(0):116-131, (2014)

3. C. X. Song, Mechanism Research and Application of Artificial Wetland for City Sewage Treatment, Dalian: Dalian Jiao Tong University, (2004)

4. Y. M. Cao, Study on Domestic Sewage of City Treatment by Artificial Wetlands, Technology of Water Treatment, 34(9):26-29, (2008)

5. J. Vymazal, L. Kröpfelová, Removal of Nitrogen in Constructed Wetlands with Horizontal Sub-sureface Flow: A Review, Wetlands, 29(4):1114-1124, (2009)

6. S. X. Yuan, M. Wang, W. Y. Chen, Z. H. Chen, J. M. $\mathrm{Hu}$, H. J. Li, F. P. Lin, Eichhornia Crassipes and Nonwoven Fabric Filter for Eutrophic Water Decontamination, Journal of Freshwater Ecology, 25(3):487-494, (2010)

7. K. Kelvin, M. Tole, The Efficacy of a Tropical Constructed Wetland for Treating Wastewater During the Dry Season: The Kenyan Experience, Water Air Soil Pollut, 215(1):137-143, (2011)

8. P. A. Bachand, A. J. Horne, Denitrification in Constructed Free-water Surface Wetlands: Ii. Effects of Vegetation and Temperature, Ecological Engineering, 14(1):17-32, (1999)

9. A. Zdragas, G. C. Zalidis, V. Takavakoglou, S. Katsavouni, E. T. Anastasiadis, K. Eskridge, A. Panoras, The Effect of Environmental Conditions on the Ability of a Constructed Wetland to Disinfect Municipal Wastewaters, Environmental Management, 29(4):510-515, (2002)

10. J. G. Zhao, L. N. Liu, Z. H. Chen, Study on removal rate of pollutants and plant growth in subsurface and surface flow constructed wetlands, Ecologic Science, 25(1):74-77, (2006)
11. J. Huang, W. Cai, Q. Zhong, S. Wang, Influence of Temperature on Micro-environment, Plant Ecophysiology and Nitrogen Removal Effect in Subsurface Flow Constructed Wetland, Ecological Engineering, 60(0):242-248, (2013)

12. A. Mietto, M. Politeo, S. Breschigliaro, M. Borin, Temperature Influence on Nitrogen Removal in a Hybrid Constructed Wetland System in Northern Italy, Ecological Engineering, 75(0):291-302, (2015)

13. W. Y. Chen, S. X. Yuan, H. J. Li, F. P. Lin, Q. Li, J. M. Hu, Z. H. Chen, Influences of temperature and light intensity on the growth and pollutant removal by Hydrillaverticillata, Acta Ecologica Sinica, 30(10):2639-2646, (2010)

14. R. H. Kadlec, Chemical, physical and biological cycles in treatment wetlands, Water Science and Technology, 40(3):37-44, (1999)

15. The Environmental Bureau of the State, Methods for Water Analysis, 4th ed., Beijing: Environmental Science Press, (2002) 210-285.

16. C. S. Akratos, V. A. Tsihrintzis, Effect of Temperature, HRT, Vegetation and Porous Media on Removal Efficiency of Pilot-scale Horizontal Subsurface Flow Constructed Wetlands, Ecological Engineering, 29(2):173-191, (2007)

17. Z. Q. Yan, M. Liu, X. Y. Wu, Y. Liu, M. T. Pan, J. H. Wang, L. T. Cai, Q. Y. Li, Z. H. Chen, Influence of Temperature on the Growth and Nutrient Removal of Five Submerged Macrophytes, Ecological Science, 33(5):839-844, (2014)

18. A. Mietto, M. Politeo, S. Breschigliaro, M. Borin, Temperature Influence on Nitrogen Removal in a Hybrid Constructed Wetland System in Northern Italy, Ecological Engineering, 75(0):291-302, (2015)

19. J. T. Wei, J. M. Wan, Research on the Characteristic and the Source of Ammonia Nitrogen in Inner-river, Environmental Monitoring in China, 22(2):62-65, (2006)

20. Y. Wang, X. W. Wu, G. Xu, Analysis of Change Law of Water Consumption in Guangzhou City, Journal of Economics of Water Resources, 25(2):4345, 83, (2007)

21. S. H. Wang, W. Wang, Y. Yu, Study on the Operating Characteristics of Subsurface Flow Constructed Wetland, China Water\& Wastewater, 19(4):4-11, (2003)

22. P. Kuschk, A. Wießner, U. Kappelmeyer, et al., Annual Cycle of Nitrogen Removal By a Pilot-scale Subsurface Horizontal Flow in a Constructed Wetland Under Moderate Climate, Water Research, 37(17):4236-4242, (2003)

23. H. B. Chen, D. B. Wang, X. M. Li, Q. Yang, K. Luo, G. M. Zeng, Temperature influence on biological phosphorus removal induced by aerobic/extendedidle regime, Environ. Sci. Pollut. Res. Int., 21(9):6034-43, (May 2014) 